Department of Biochemistry (Prof. S. Mizuhara), Okayama University Medical School, Okayama, Japan; Department of Microbiology (Prof. Y. AkISADA), Kyushu Dental College; Department of Anatomy (Prof. T. FujiTA), Niigata University Medical School; and Department of Pathology (Prof. S. Seno), Okayama University Medical School

\title{
Scanning Electron Microscopy of Isolated Mitochondria I
}

\author{
Kengo Kurahasi, Junichi Tokunaga, Tsuneo Fujita and Masanobu Miyahara \\ （倉橋研吾，德永純一，藤田恒夫，宮原正信）
}

Received November 20, 1968

The recent development of scanning electron microscopy has enabled the surface investigation of biological materials. Besides works on hard tissues several reports dealing with the surface structures of soft tissues, cells and intracellular organelles such as chromosomes have appeared (PEASE and HAYES, 1966; CLARKE and Salsbury, 1967; Christenhuss, Büchner and Pfeiffer, 1967; Pawlowitzki, Blaschke and Christenhuss, 1968; Barber and Boyde, 1968; Fujita, Inoue and Kodama, 1968; etc.).

In certain fields of biochemistry the investigation of biological activities in correlation with morphological structures has become one of the most important. The transmission electron microscope has been used either to clarify the relationship between the location of biological activity and the cellular or subcellular fractions, or to check the purity and morphological character of the fractions. Conventional electron microscopy, however, requires skill and time for the preparation of specimens, especially in embedding and sectioning procedures.

In the present scanning electron microscope study which was initiated in an attempt to check quickly the purity of isolated mitochondria used in biochemical studies, it was noticed that mitochondria from different organs and prepared in different media displayed various interesting and suggestive features in their surface structures under the scanning electron microscope. The shape of each mitochondrion in toto could clearly be visualized with this method.

Besides technical comments and general findings this paper will treat with the effects of the concentrations of sucrose used in preparation on the morphological appearance of isolated mitochondria under the scanning electron microscope. Possible mechanism of morphological changes in isolated mitochondria will be discussed.

As far as the authors know, there seems to have been published only a short paper by ClARKE and his co-workers (1968) in the application of the scanning electron microscope to subcellular fractions. The picture of mitochondrion shown by them, however, is hardly recognizable as such (vide infra). The present paper might then provide the first convincing pictures and descriptions on isolated mitochondria under the scanning electron microscope. 


\section{Material and Method}

The materials of this study were comprised mainly of livers and some kidneys and gastrocnemius muscles obtained from adult albino rats of both sexes killed by breaking the neck with a blow.

\section{Isolation of Mitochondria}

The liver was homogenized in ten volumes of an ice-cold $0.25 \mathrm{M}, 0.32 \mathrm{M}$ or $0.44 \mathrm{M}$ sucrose solution using a Potter-Elvejem homogenizer with teflon pestle. The homogenate in $0.25 \mathrm{M}$ sucrose was centrifuged at $500 \times \mathrm{g}$ for $10 \mathrm{~min}$ to remove nuclei and cell debris. The supernatant was layered on $20 \mathrm{ml}$ of $0.34 \mathrm{M}$ sucrose and centrifuged at $700 \times \mathrm{g}$ for $10 \mathrm{~min}$. The $0.25 \mathrm{M}$ fraction was centrifuged at $6,000 \times \mathrm{g}$ for $10 \mathrm{~min}$ and the sediment thus obtained was washed twice in the same sucrose solution. The homogenate prepared in $0.32 \mathrm{M}$ sucrose was centrifuged at $700 \times \mathrm{g}$ for 10 min. The supernatant was centrifuged again in the same way to remove remaining nuclei and cell debris. Mitochondria were precipitated by centrifugation at 8,000 $\times \mathrm{g}$ for $10 \mathrm{~min}$ and were washed twice. From the homogenate prepared in $0.44 \mathrm{M}$ sucrose nuclei and cell debris were removed by centrifugation at $2,100 \times \mathrm{g}$ for 10 min and the supernatant was centrifuged again. Mitochondria were precipitated at $12,000 \times \mathrm{g}$ for $10 \mathrm{~min}$ and washed twice with the same sucrose solution.

Mitochondria of the kidney were prepared according to the same procedure as that of the liver using $0.32 \mathrm{M}$ sucrose. For preparing the muscular mitochondria Chappell-Perry medium was employed according to ERNSTER and Nordenbrand (1967).

\section{Measurement of biological activities}

Prior to fixation in glutaraldehyde (vide infra), mitochondrial activities were measured polarographically with Clark oxygen electrode. Mitochondria corresponding to $4 \mathrm{mg}$ protein were suspended in $2.0 \mathrm{ml}$ of medium composed of $20 \mathrm{mM}$

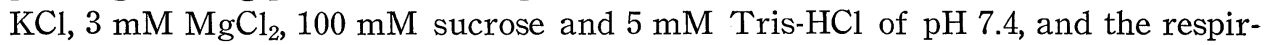
atory control index and ADP : O ratio were estimated as described elsewhere.

\section{Preparation of specimens for scanning electron microscopy}

The isolated mitochondria were suspended in $2.5 \%$ glutaraldehyde in $5 \mathrm{mM}$ Tris buffer adjusted to $\mathrm{pH} 7.4$ containing $20 \mathrm{mM} \mathrm{KCl}, 5 \mathrm{mM}$ succinate and sucrose of the same concentration as that used for the preparation of mitochondria, and allowed to stand for $20 \mathrm{~min}$ at room temperature. The mitochondria were precipitated with a table centrifuge; the supernatant was replaced by water containing a series of increasing concentrations of acetone $(0,50,70,90,95$ and $100 \%)$. The mitochondria thus dehydrated were finally suspended in a small amount of dried acetone. Drops of this suspension were spread with a pipette on small pieces of slide glass $(1 \times 1.5 \mathrm{~cm})$ under gentle drafts of warm air. Storage of the air dried samples in a desiccator for several weeks did not cause any additional change to the mitochondria in appearance. The samples thus dried were coated with carbon and gold in a vacuum evapolator equipped with a rotating devise. During the 
coating procedure in which carbon and gold vapors were cast with an angle of 45 to $60^{\circ}$ against the plane plate on which the samples were placed, the plate was rotated horizontally in order to ensure even coverage. The preparations, either before or after coating, were observed under the light microscope with dark-field illumination to eliminate unsuitable samples for scanning electron microscopy. A scanning electron microscope, Type JSM-2 (Japan Electron Optics Laboratory Co., Ltd.), was used for observation and the photography was done with $25 \mathrm{KV}$ accelerating voltage.

\section{Observations}

Liver mitochondria prepared in $0.25 M$ sucrose generally were spherical in appearance and showed varing sizes, mostly falling in the range from 0.4 to $0.7 \mu$ in diameter (Fig. 1-5). Their surfaces were not smooth but rather rough and provided with grooves ( $a$ in Figures 2 and 3), a single bore or dent ( $b$ in Figures 2 and 3), tubercular or lumpy elevations ( $c$ in Figures 3.4 and 5), and occasionally with rodlike processes ( $d$ in Figure 4 ). There were also encountered mulberry-like partcles (e in Figure 5).

These preparations, prior to fixation, showed a respiratory control indexes by 3.6 to 5.4 , and ADP : O ratios by 1.4 to 2.2 .

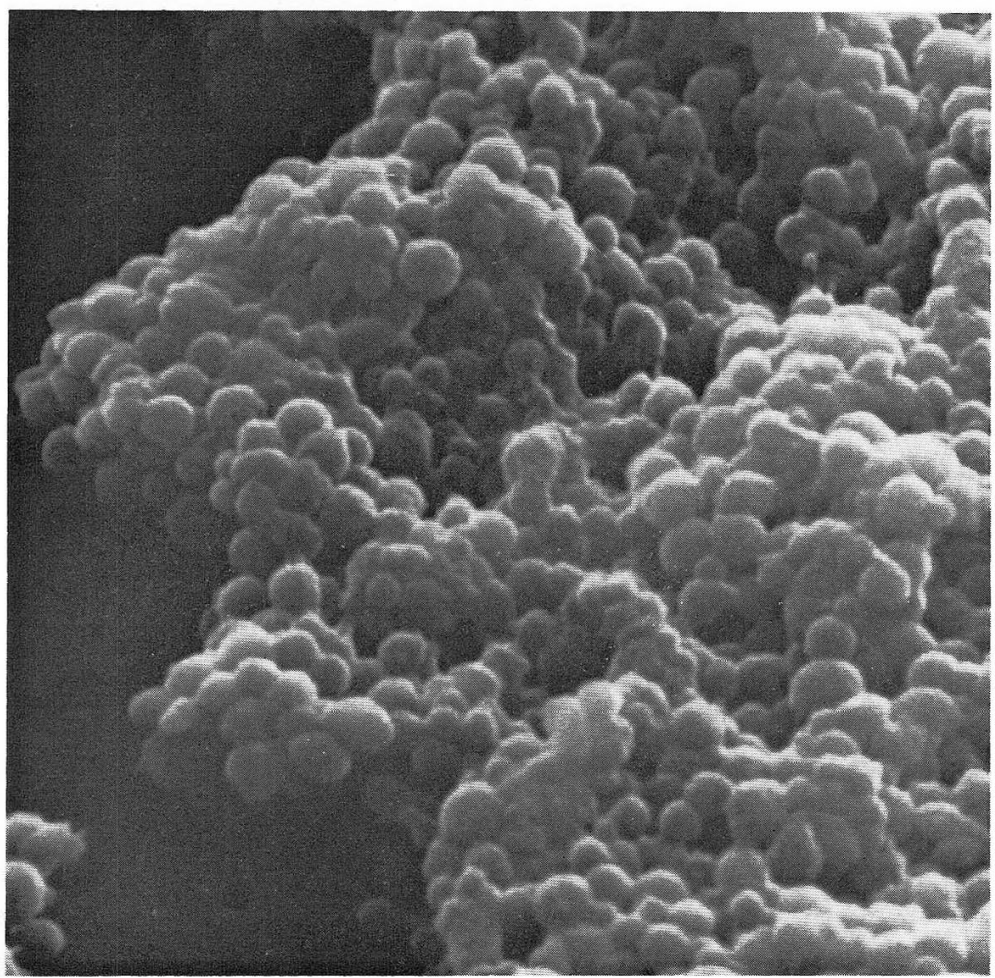

Fig. 1. Liver mitochondria prepared in 0.25 M sucrose. $\times 9,000$ 


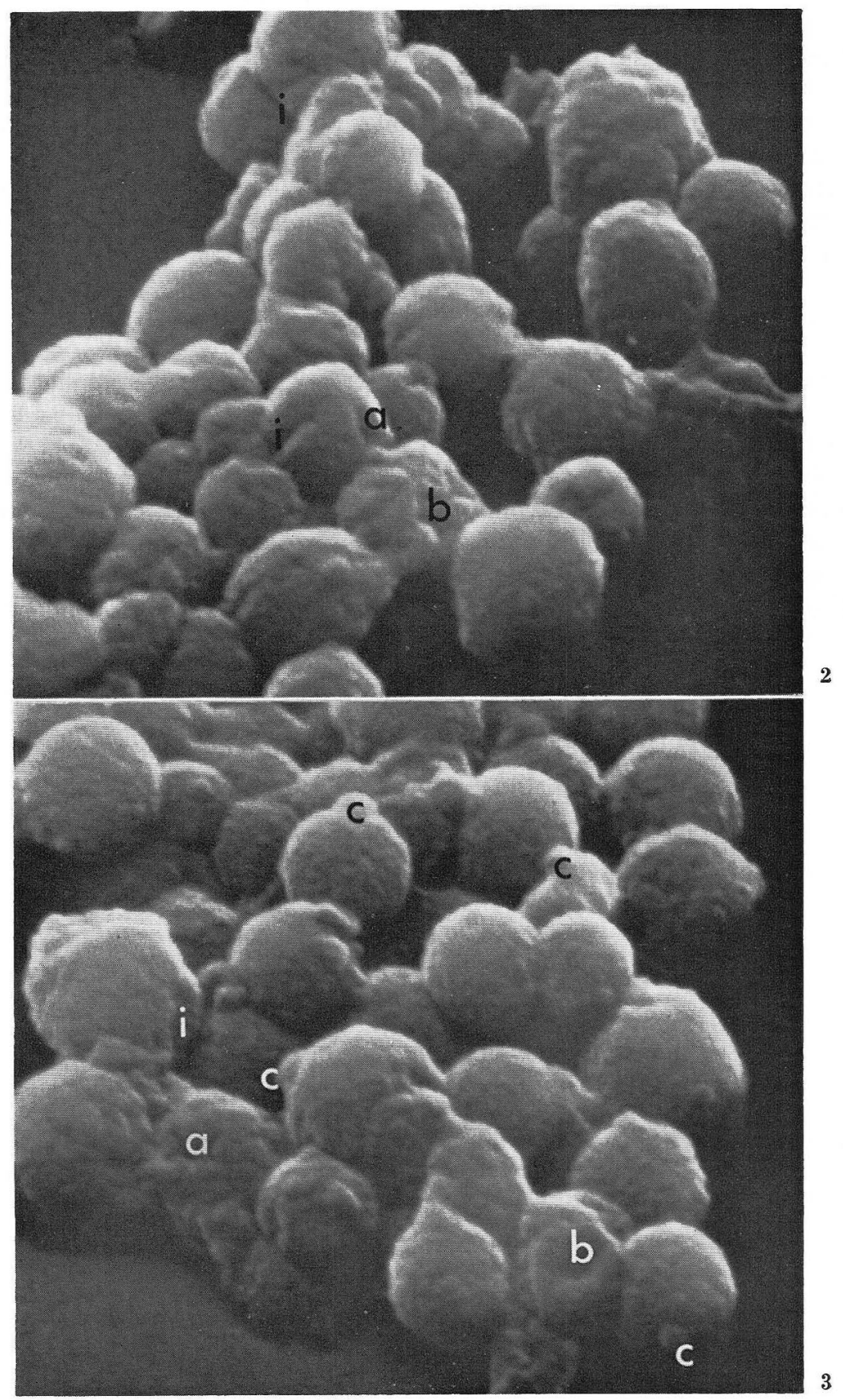

Fig. 2 and 3. Liver mitochondria prepared in $0.25 \mathrm{M}$ sucrose in higher magnification. Grooves $(a)$, a central dent $(b)$ and tubercles or lumpy elevations $(c)$ are seen on the surface of mitochondria. $\times 30,000$ 
4
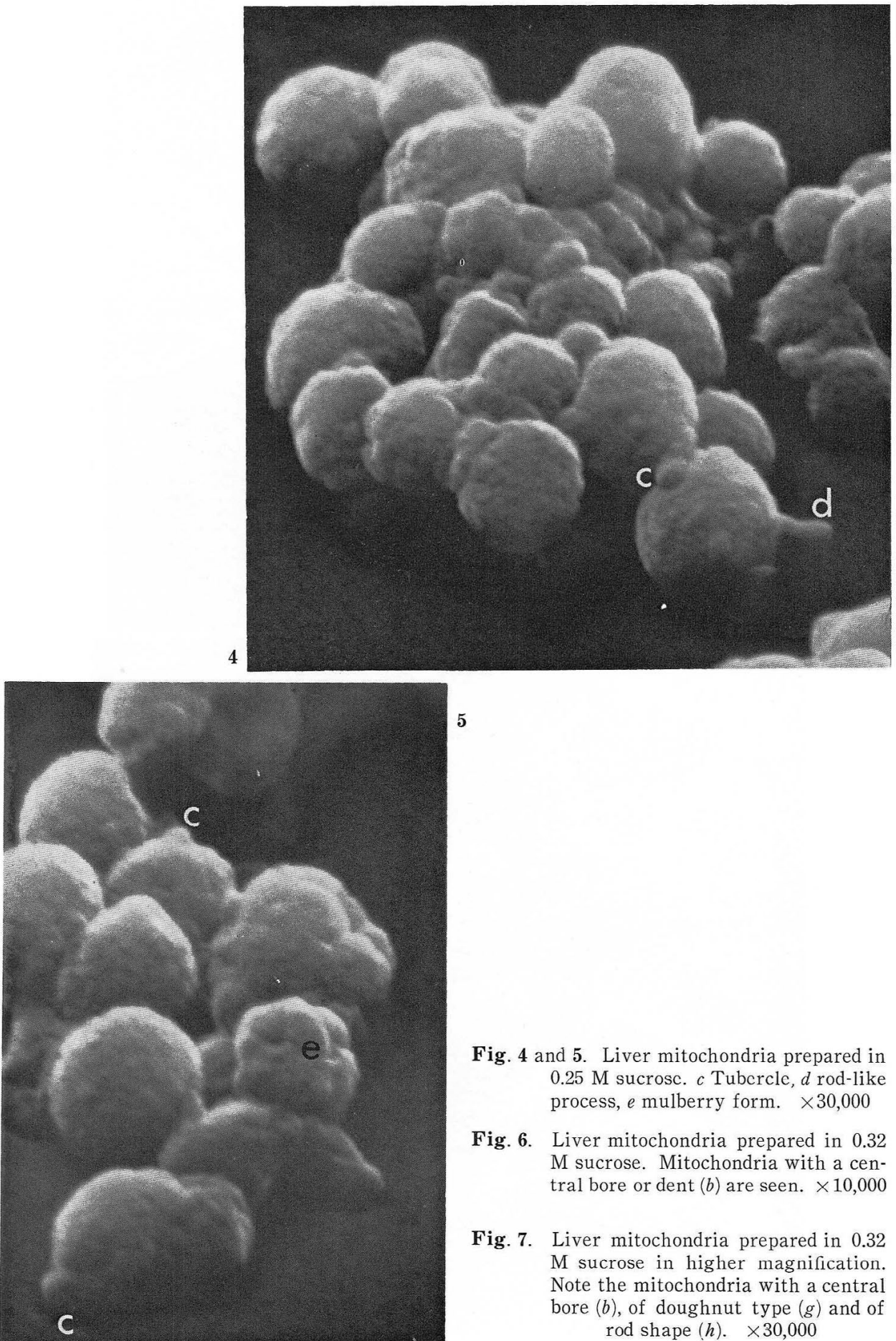

Fig. 4 and 5. Liver mitochondria prepared in $0.25 \mathrm{M}$ sucrosc. $c$ Tubcrcle, $d$ rod-like process, $e$ mulberry form. $\quad \times 30,000$

Fig. 6. Liver mitochondria prepared in 0.32 $M$ sucrose. Mitochondria with a central bore or dent $(b)$ are seen. $\times 10,000$

Fig. 7. Liver mitochondria prepared in 0.32 $\mathrm{M}$ sucrose in higher magnification. Note the mitochondria with a central bore $(b)$, of doughnut type $(g)$ and of rod shape $(h) . \quad \times 30,000$ 

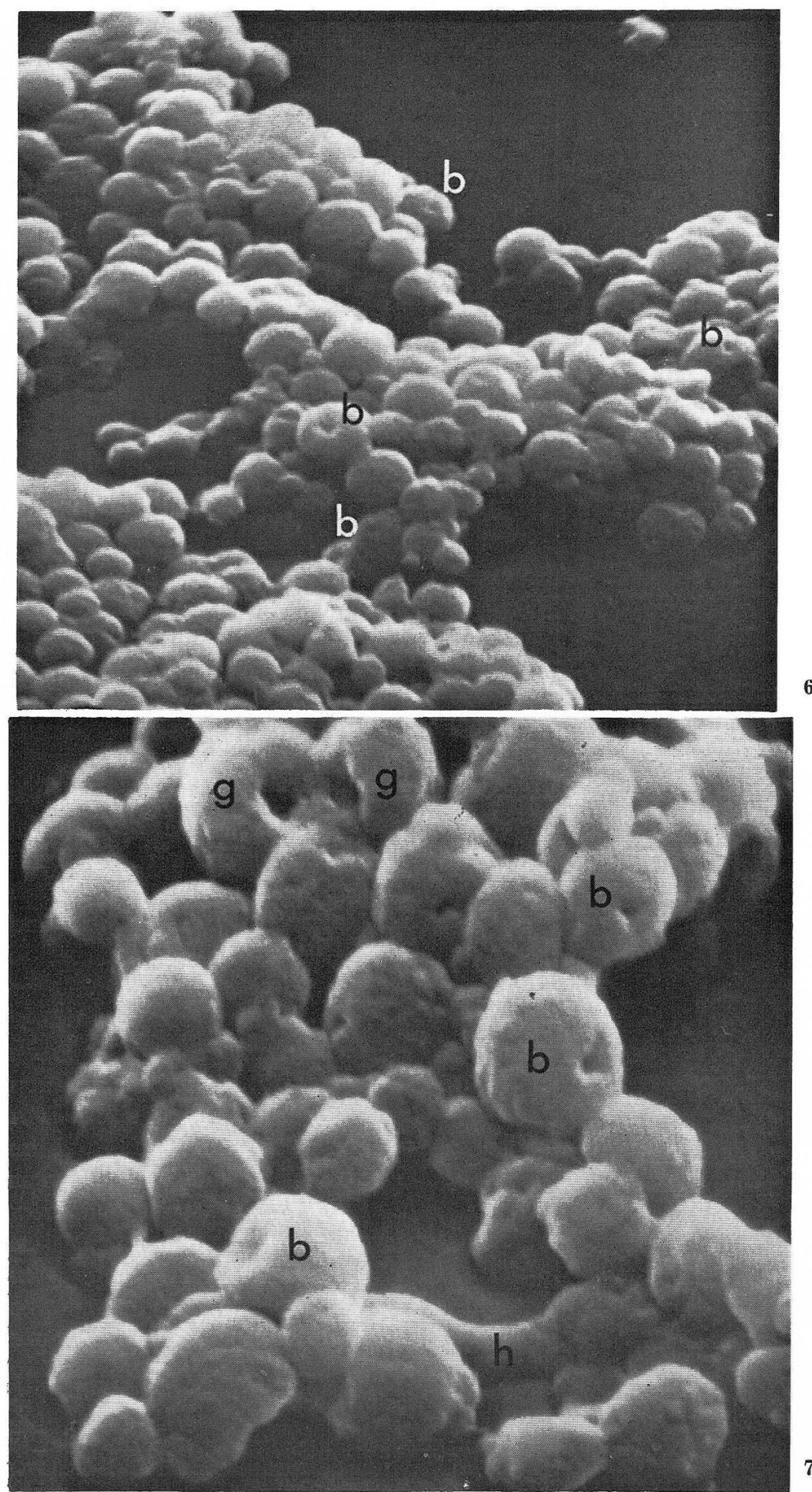

Fig. 6 and 7. For legend see p. 221. 


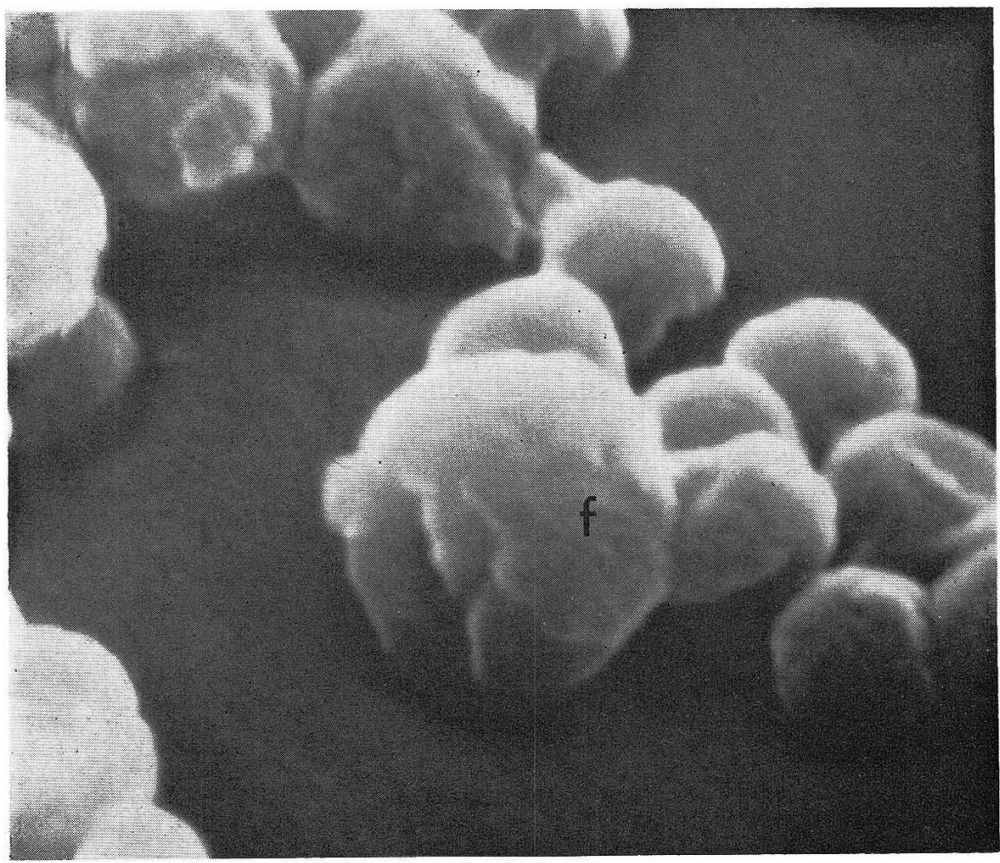

Fig. 8. Liver mitochondria prepared in $0.32 \mathrm{M}$ sucrose, $f$ Rolled worm type. $\times 40,000$

Tiver mitochondria prepared in $0.32 M$ sucrose were rather oval in shape (Fig. 6 -8). They differed not significantly in appearance and size from those prepared in $0.25 \mathrm{M}$ sucrose except for the occurrence of a single and distinct bore ( $b$ in Figures 6 and 7) which was so deep that it seemed to penetrate the whole mitochondrial body. This borc really caused in some mitochondria the appearance of a rolled worm ( $f$ in Figure 8) or of a doughnut ( $g$ in Figure 7 ) which did not appear in specimens prepared in $0.25 \mathrm{M}$ sucrose.

Liver mitochondria prepared in $0.44 M$ sucrose (Fig. 9-13) were more polymorphic. Besides ovoid forms with more or less uneven surfaces, there occurred mitochondria of a distinct rod shape (length: $1 \mu$ ), either straight or curved $(h$ in Figures 10 and 13). Forms characterized by several incisions were also encountered ( $i$ in Figures 11, 12 and 13). Doughnut and rolled forms werc rather less frequently observed.

Mitochondria of the kidney (Fig. 14-16), measuring 0.2 to $0.7 \mu$ in diameter, were more variable in shape and size than those of the liver, spherical forms being encountered less frequently. The majority were shaped either like doughnuts ( $g$ in Figures 14, 15 and 16) or like rolled larvae ( $f$ in Figures 14 and 16). Their surfaces were more or less uneven with lumpy elevations.

Muscle mitochondria in the present specimens (Fig. 17-19) were contaminated with string-like and small particulate structures. The former may correspond to 


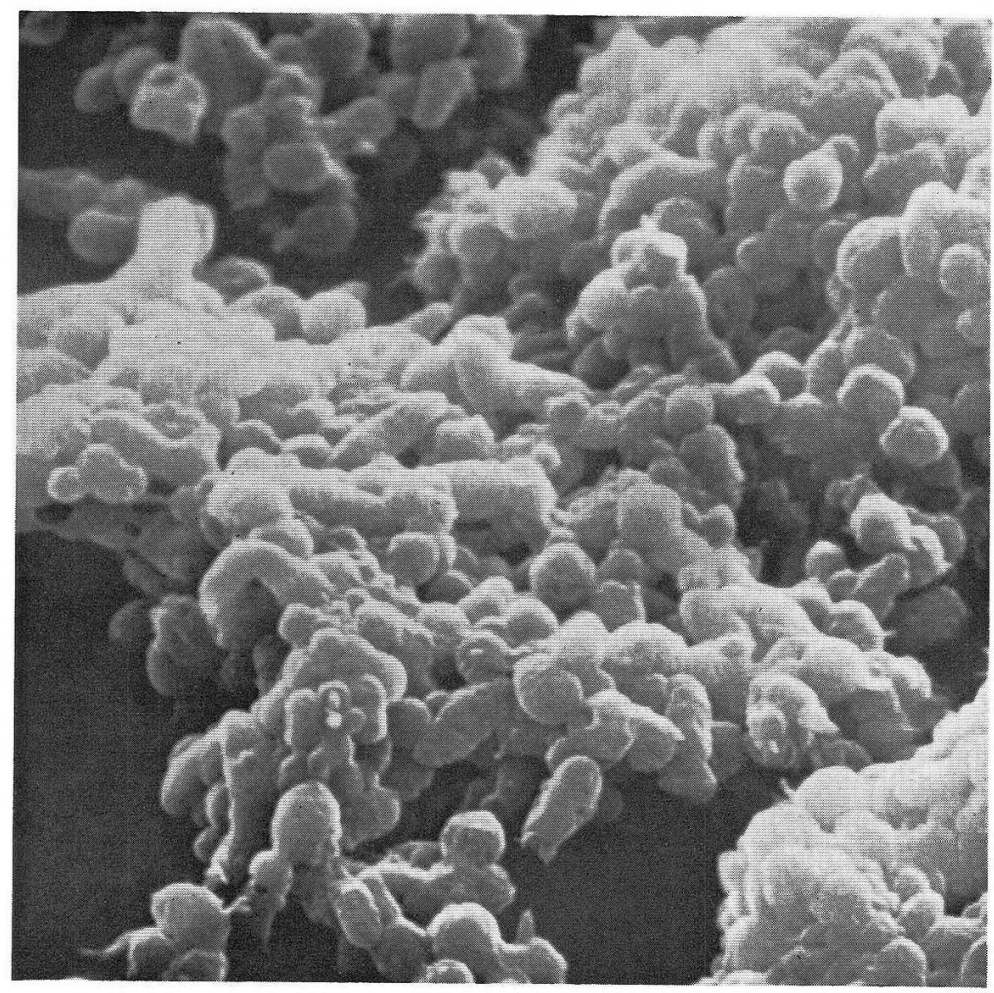

Fig. 9. Liver mitochondria prepared in $0.44 \mathrm{M}$ sucrose. Many rod-like mitochondria are seen in this preparation. $\times 10,000$

the myofibrile bundles. The mitochondria varied in shape and size so conspicuously that it sometimes was difficult to distinguish them from the contaminants. Some of elongated mitochondria were beaded with a constricted part or parts (Fig. 19). This type was seen rclatively often in musele mitochondria. It was often unclear whether it corresponded to a long mitochondrion or to a chain of two or more mitochondria. Unknown reason or reasons prevented displaying the detailed surface of muscle mitochondria.

\section{Discussion}

At the present stage of this study it is impossible to distinguish mitochondria from other subcellular components such as lysosomes or peroxisomes which are known to precipitate with mitochondria. Since the population of these particles is very small in comparison with that of mitochondria, majority of the particles appearing in the pictures should be identified with mitochondria.

The procedures of dehydrating the isolated mitochondria with acetone and drying them on the slide glass in warm air employed in the present study principally correspond to the method used by BARBER and BOYDE (1968) for the observation of mucous membranes, and by Fujita, Inoue and Kodama (1968) for the study of 




Fig. 10-13. Liver mitochondria prepared in $0.44 \mathrm{M}$ sucrose in higher magnification. $f$ Rolled worm type, $h$ rod type, $i$ incisions on the mitochondrial surface. $\times 40,000$ 

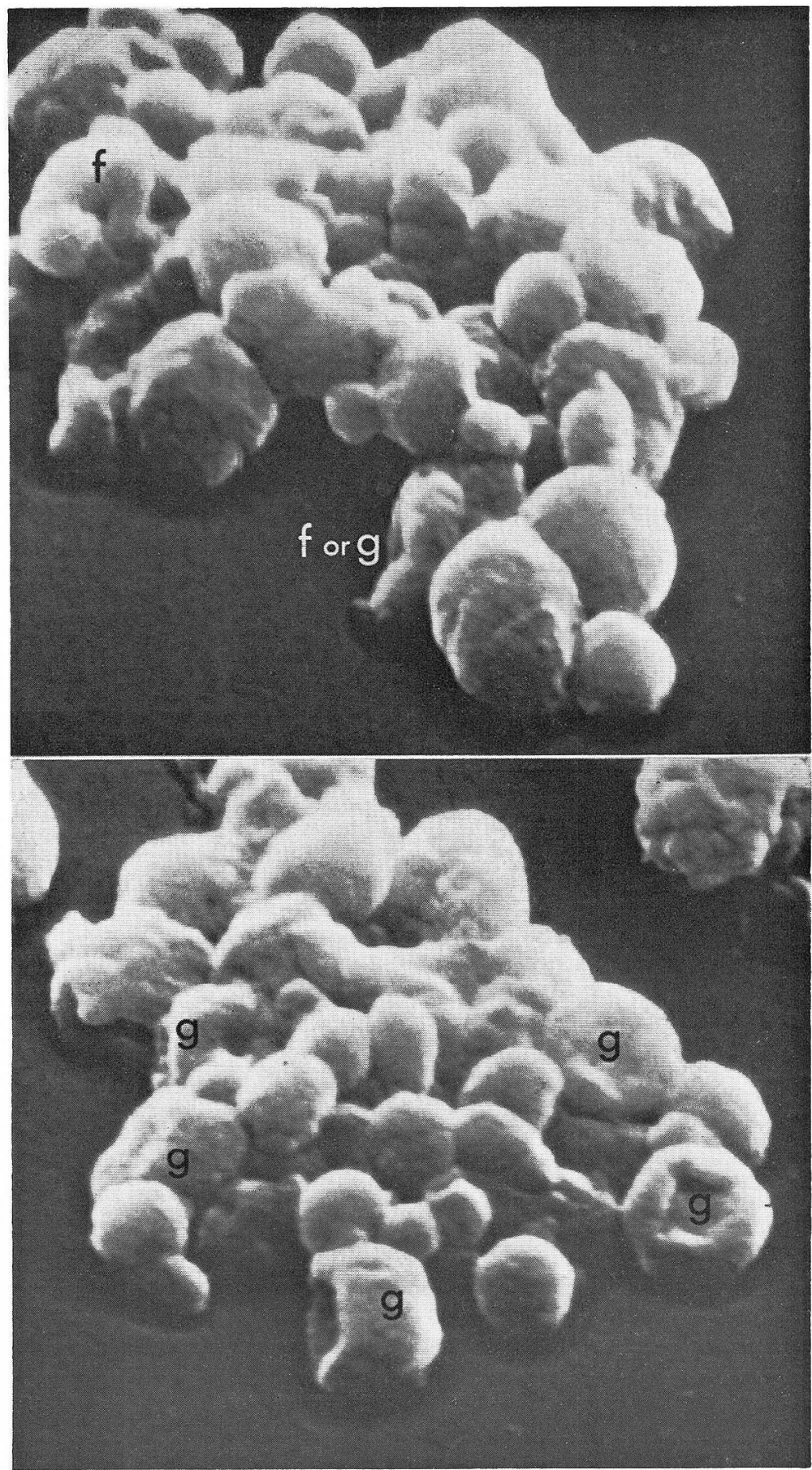

Fig. 14-16. Kidney mitochondria prepared in $0.32 \mathrm{M}$ sucrose. Forms of rolled worm $(f)$ and doughnut $(g)$ are recognized. Fig. 14 and $15: \times 30,000$; Fig. $16: \times 40,000$ 


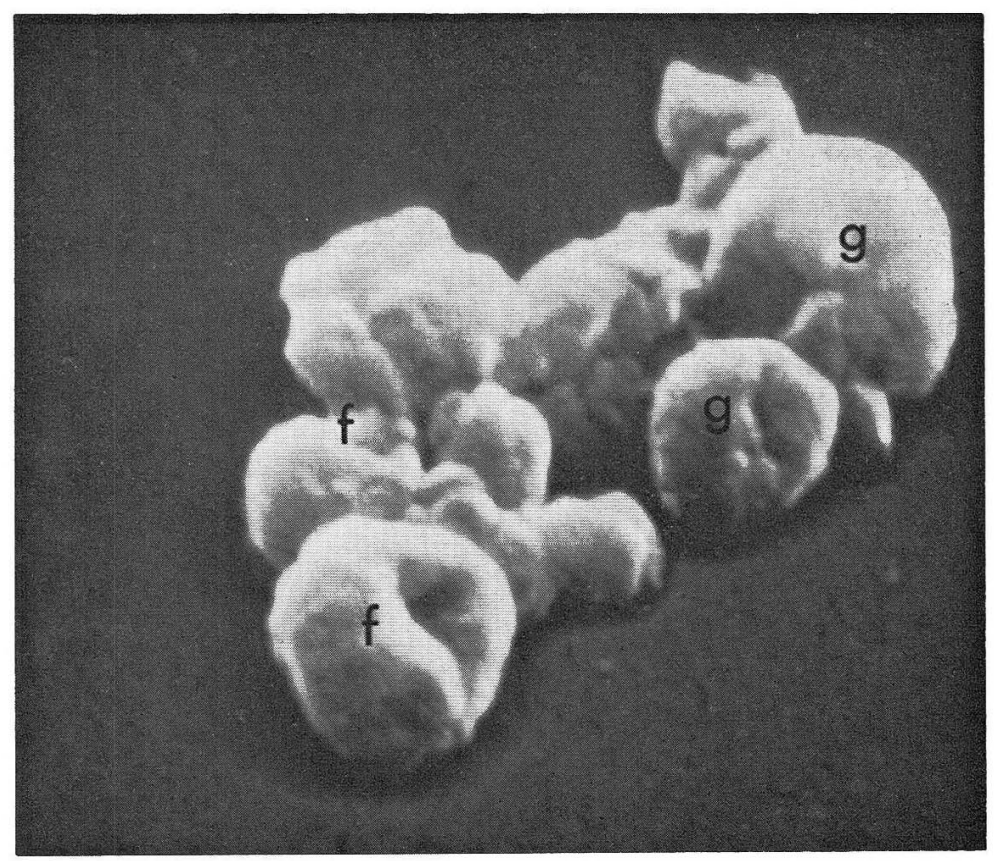

Fig. 16. For legend see under Figure 15.

synovial surfaces. This simple, quick procedure is especially suited to the electron microscopic check and morphological analysis of fractionated materials. Besides mitochondria other subcellular fractions such as nuclei isolated from liver cells and synaptic endings from rat brain were treated with the same method and successfully observed under the scanning electron microscope by the present authors.

The different shapes in mitochondria described above, especially in those of the liver prepared in $0.44 \mathrm{M}$ sucrose and of the kideny, seem to imply their morphological changes including a process of bending or rolling up of their original rod form. Through crescentic and helical forms they might be finally converted into the doughnut form by the fusion of their outer membranes. The spherical forms which are the predominant type of mitochondria prepared in $0.25 \mathrm{M}$ sucrose may be produced by the doughnut form swelling up in the slightly hypotonic solution.

The prcsumptive mechanism of the formation of a doughnut described above is supported by the picture shown in Figure 12 in which both ends of a rolled mitochondrion $(f)$ are not in fusion but in contact with each other leaving a cleft in between. This seems to indicate a possible stage before the ring closes. Further, this picture is advantageous for excluding the argument that the doughnut shape of mitochondrion should be ascribed to an apparent "fusion" at their ends caused by the coating of carbon and gold.

The mitochondria which showed several large incisions on the surface might have been produced by the osmotic effect of $0.44 \mathrm{M}$ sucrose, i.e., by the drawing out of water croass the mitochondrial membranes due to the hypertonic sucrose solution. Re-suspension of mitochondria prepared in $0.44 \mathrm{M}$ sucrose in an isotonic 

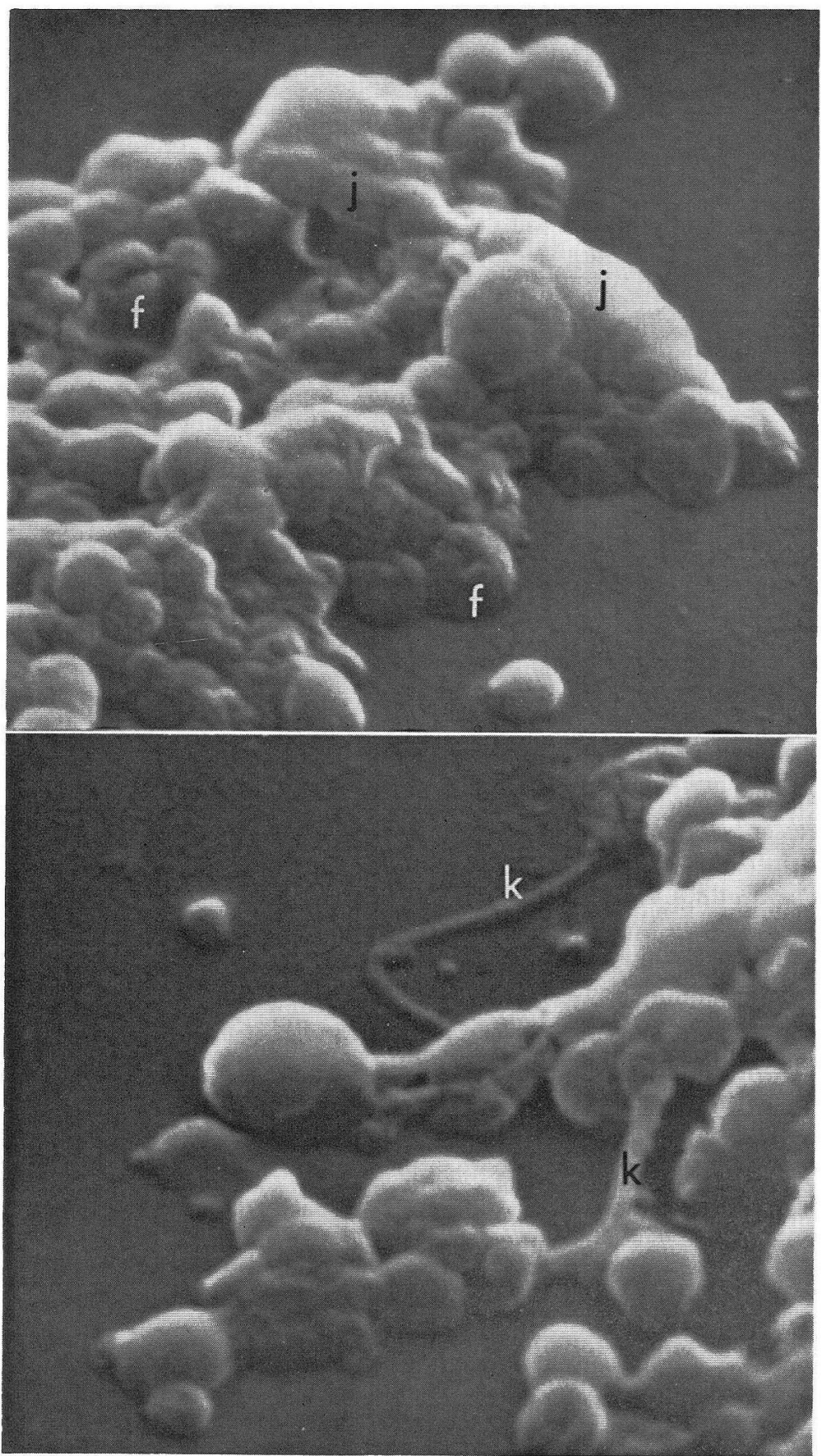

Fig. 17 and 18. Muscle mitochondria prepared in Chappell-Perry medium. Besides forms of rolled worm $(f)$, beaded arrangement of mitochondria $(j)$ and fibrous contaminations $(k)$ are recognized. $\times 30,000$ 


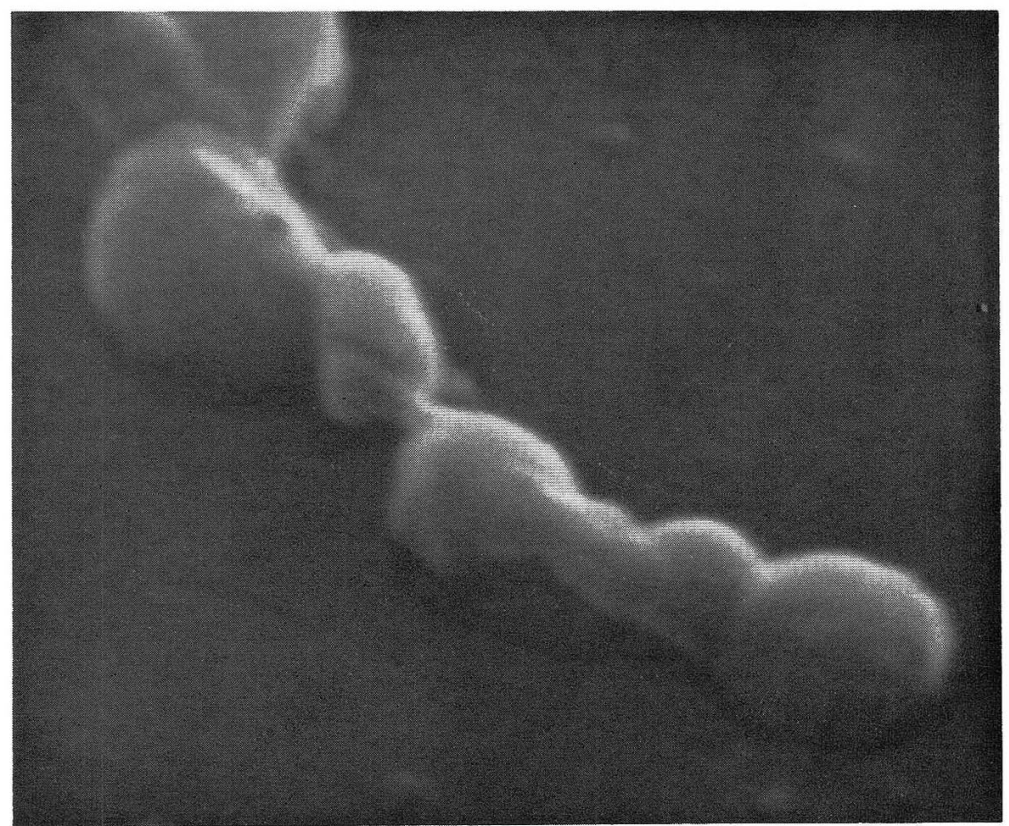

Fig. 19. Mitochondria of beaded type in the same preparation as shown in Figures 17 and $18 . \times 50,000$

buffer of pH 7.4 containing $20 \mathrm{mM}$ phosphate caused a spherical swelling by imbibing of water (Fig. 20,21). The mitochondria thus treated showed only one notch on their semispherical surface (Fig. 21).

The rough surfaces of mitochondria might reflect their inner structures. In a comparison of mitochondria prepared in $0.25 \mathrm{M}$ sucrose with those prepared in 0.32 $\mathrm{M}$, no significant swelling appeared to be produced in the slightly hypotonic medium; little change in the surfaces was observed except for more frequent bores and dents on the surfaces of mitochondria prepared in the $0.32 \mathrm{M}$ sucrose. Tubercular elevations and rod-like processes may be caused by extension of the mitochondrial membranes and may be considered an early stage in the possible fission of mitochondria as SwIFT (1968) described on oocyte mitochondria.

Although WHITTAKER (1966) observed rat liver mitochondria in conspicuously elongated forms when prepared in $0.44 \mathrm{M}$ sucrose and stained negatively, NEubERT (1966) claimed that he found no elongated form in the corresponding preparation. ROUILLer (1960) also did not show this form. In the present study it was impossible to see this form in the rat liver mitochondria prepared in $0.44 \mathrm{M}$ sucrose.

In the present observation it is clear that the concentrations of the sucrose solutions used in the preparation of mitochondria caused definite changes in the shape of mitochondria. It can be argued that the concentration of the fixative may possibly cause additional morphological changes in the mitochondria. The effect of the concentration of the glutalaldehyde, if present at all, is believed to be insignificant because the appearance of mitochondria after $5 \%$ glutalaldehyde fixation differed insignificantly from that after $2.5 \%$ fixation employed in the present 


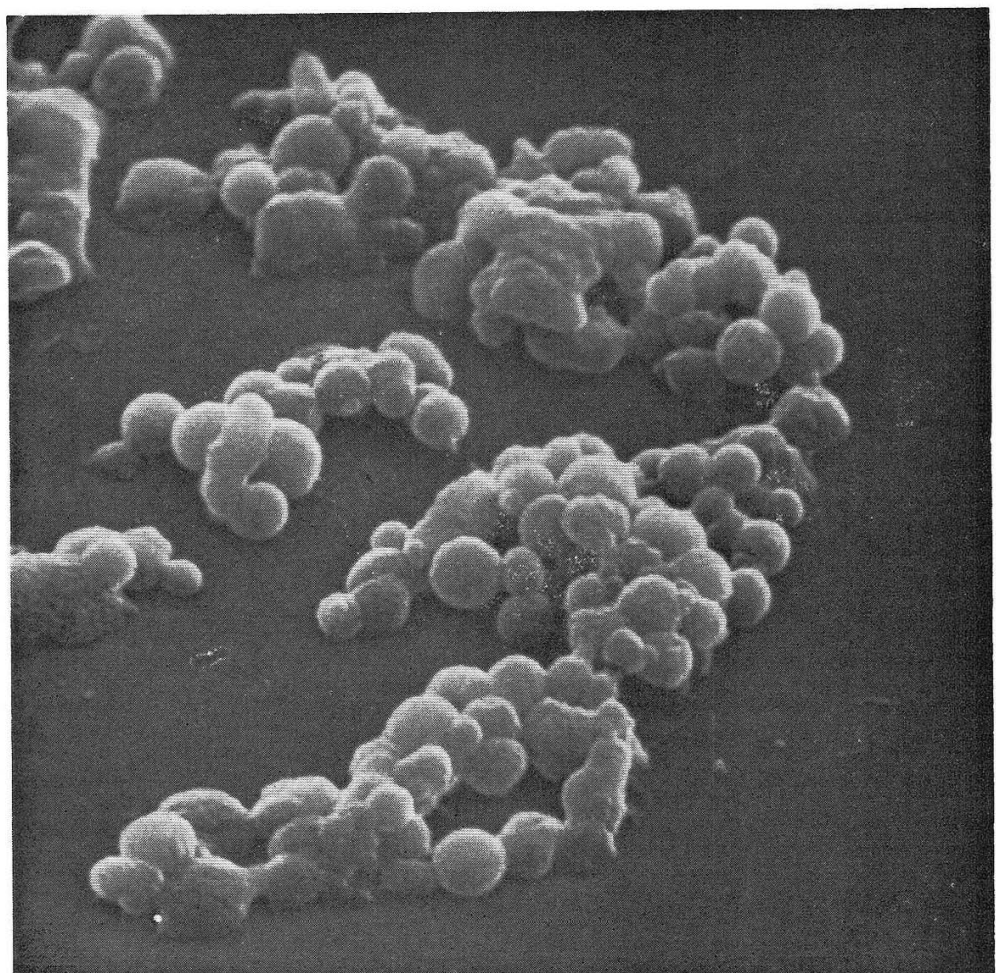

Fig. 20. Liver mitochondria prepared in $0.44 \mathrm{M}$ sucrose and treated successively in an isotonic buffer containing $20 \mathrm{mM}$ phosphate. $\times 10,000$

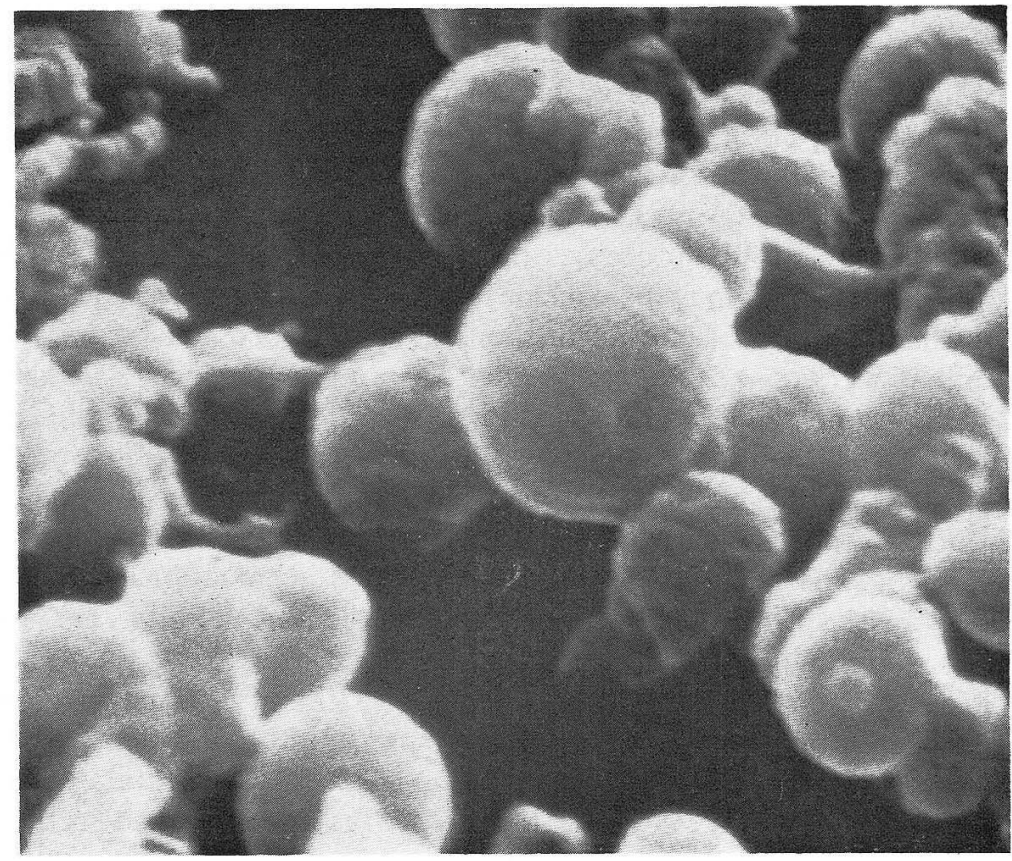

Fig. 21. The same preparation as shown in Figure 20 in higher magnification. $\times 30,000$ 
study.

In a review on scanning electron microscopy Clarke et al. (1968) showed a picture of "a rat liver mitochondrion." It is very difficult, however, to identify the irregularly shaped structure shown there as a mitochondrion, because of its size $(3 \times 5 \mu)$ which is quite different from that found in the literature and in the present study. The small spherical particles at the left lower corner in Figure 16 in their report may better correspond to mitochondria in appearance and in size.

\section{Summary}

Acetone-dehydrated and air-dried spread specimens of mitochondria isolated from the liver, kidney and skeletal muscle of the rat were observed under the scanning electron microscope.

The mitochondria from the liver differed in shape according to the concentrations of sucrose used in preparation. They were of ovoid and rod-like shape when $0.44 \mathrm{M}$ sucrose was used. With $0.32 \mathrm{M}$ sucrose they resembled either rolled larvae or doughnuts. With $0.25 \mathrm{M}$ sucrose spherical forms were predominant. Processes of rolling up of the original rod shape into a ring and its swelling into a spherical form in hypotonic media were suggested.

The mitochondria from the kidney and muscle were less uniform in shape and size than those from the liver.

\section{走査電子鏡によるミトコンドリア分画の観察一I（内容自抄）}

ラットの肝臓, 腎臓, 骨格筋から分離したミトコンドリアをアセトン脱水後 ガラス 上で空気乾燥させて得た標本を 走査電子鏡で観察した.

肝臓のミトコンドリアは調製に用いる䓞糖の濃度に応じて異なった形を示した. 0.44 M の蔗糖を用いるときは，卵形や棒状を呈するが， $0.32 \mathrm{M}$ では巻いたウジ虫やドーナ ツの形をとり，0.25Mでは球形が多かった。もともと棒状のミトコンドリアが輪状に巻 きこみ, 低調液の影響のもとではとれがさらに膨化して球状となる過程が想定された.

腎臓と筋から得られたミトコンドリアは，肝藏のものより形と大きさが不揃いであっ た.

\section{References}

Barber, V. C. and A. Boyde: Scanning electron microscopic studies of cilia. Z. Zellforsch. 84 : 269-284 (1968).

Christenhuss, R., Th. Büchner and R. A. Pfeiffer : Visualization of human somatic chromosomes by scanning electron microscopy. Nature $216 ; 379-380$ (1967).

Clarke, J. A. and A. J. Salsbury : Surface ultramicroscopy of human blood cells. Nature 215 : 402-404 (1967).

Clarke, J. A., A. J. Salsbury and G. J. Rowland : The scanning electron microscope II. Sci. J. : 54-61 (1968). 
Ernster, L. and K. Nordenbrand : In : (ed. by) R. W. Estabrook and M. E. Pullman : Methods in enzymology Vol. 10. New York, Academic Press, 1967 (p. 86-94).

Fujita, T., H. Inoue and T. Kodama : Scanning electron microscopy of the normal and rheumatoid synovial membranes. Arch. histol. jap. 29 : 511-522 (1968).

Neubert, W.: Cited from V. P. Whittaker, in : (ed. by) J. M. Tager et al. : Regeneration of metabolic processes in mitochondria. BBA Library Vol. 7 Amsterdam, Elsevier, 1966 (p. 1-27).

Pawlowitzki, I. H., R. Blaschke und R. Christenhuss : Darstellung von Chromosomen im RasterElektronenmikroskop nach Enzymbehandlung. Naturwiss. 55 : 63-64 (1968).

Pease, R. F. W. and T. L. Hayes : Scanning electron microscopy of biological material. Nature $210: 1049$ (1966).

Rouiller, Ch.: Physiological and pathological change in mitochondrial morphology. Int. Rev. Cytol. 9 : 227-291 (1960).

Swift H. : Cited from B. Kadenbach, in : (ed. by) E. C. Slater et al. : Biochemical aspects of the biogenesis of mitochondria. Bari, Adriatica Editrice, 1968 (p. 415-438).

Whittaker, V.P.: The ultrastructure of mitochondria. In : (ed. by) J. M. Tager et al. : Regulation of metabolic processes in mitochondria. BBA Library Vol. 7. Amsterdam, Elsevier, 1966 (p. 1-27). 